\title{
Predominance of HBV genotype D in southern part of India
}

\author{
Kalyanaraman Narayanan ${ }^{1}$, L Thayumanavan², Jayalakshmi Mariakuttikan ${ }^{1 *}$ \\ From 2nd International Science Symposium on HIV and Infectious Diseases (HIV SCIENCE 2014) \\ Chennai, India. 30 January - 1 February 2014
}

\section{Background}

The clinical outcome of HBV infection is highly heterogeneous which correlates with viral factors such as genotypes, viremia and mutants. Evidences showed that HBV genotypes have a role in prevalence of variants, IFN therapy and disease severity. So far, $10 \mathrm{HBV}$ genotypes (A to J) have been identified with distinct geographical distribution. Hence, knowledge of the genotype infecting an individual may assist a physician making a decision towards better clinical management. The aim of this study is to identify the circulating HBV genotypes (A e) and its correlation with clinical manifestation.

\section{Methods}

A cohort of 72 patients (Acute: 11; Asymptomatic: 36; Chronic: 24; and HCC: 1 ) attending the Govt. Rajaji Hospital, Madurai, was recruited. Clinical categorization was based on biochemical and viral markers. Viral DNA extraction was carried out from serum samples and genotyping was done by multiplex PCR.

\section{Results}

Multiplex PCR was optimized with viral reference samples. Each reaction was carried out with five pairs of primers. We could observe only genotype D in this cohort $(100 \%)$. None of the samples were assigned with other genotypes.

\section{Conclusion}

$\mathrm{HBV}$ genotype $\mathrm{D}$ has a major role in emergence of precore mutants (1896 G>A) leading to diagnostic failure, vaccine escape mutants, and poor clinical response while therapy.

\footnotetext{
* Correspondence: jayalakshmim@genomicsmku.org

'Department of Immunology, School of Biological Sciences, Madurai Kamaraj University, Madurai, India

Full list of author information is available at the end of the article
}

\section{Authors' details}

'Department of Immunology, School of Biological Sciences, Madurai Kamaraj University, Madurai, India. ${ }^{2}$ Department of Gastroenterology, Govt Rajaji Hospital, Madurai, India.

Published: 27 May 2014

doi:10.1186/1471-2334-14-S3-P22

Cite this article as: Narayanan et al:: Predominance of HBV genotype D in southern part of India. BMC Infectious Diseases 2014 14(Suppl 3):P22.
Submit your next manuscript to BioMed Central and take full advantage of:

- Convenient online submission

- Thorough peer review

- No space constraints or color figure charges

- Immediate publication on acceptance

- Inclusion in PubMed, CAS, Scopus and Google Scholar

- Research which is freely available for redistribution

Submit your manuscript at www.biomedcentral.com/submit
( Biomed Central

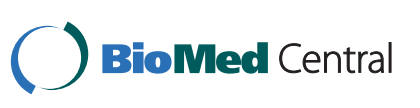

